\title{
1 \\ SETTING A NEW PARADIGM IN WORLD ORDER The United Nations action in Korea
}

\author{
Robert O'Neill
}

In June 1950, the Republic of Korea (ROK) was essentially occupied by the Democratic People's Republic of Korea's (DPRK) Korean People's Army (KPA). ${ }^{1}$ Its people were dying or being slaughtered in the thousands. Its army was shattered, and all that remained under its control was the tiny area within the Pusan Perimeter in the south-east corner of the peninsula. Today the ROK is a powerful, thriving state, recently rated as the most wired via the Internet of all countries in the world. Its science and maths students are winning global awards for their outstanding intellectual performance. It is a marked difference, and a tribute both to the Korean people themselves and to those who placed their lives on the line to help them recover: first by repelling the invaders; second by fighting their more powerful allies to a standstill; and third by imparting the lessons that have enabled the South Koreans to be largely self-sufficient in security while creating a strong economy and a progressive, democratic society since the ceasefire in 1953.

\footnotetext{
1 This chapter is based on Robert O'Neill's presentation at the international military history conference 'Korea: In from the Cold', Australian War Memorial, Canberra, 2011.
} 
The Korean War was a severe test for Western leaders, political and military, and for the soldiers, sailors and airmen under their command. It was a long, frustrating and bloody conflict. The Korean War achieved its aims and laid the basis for those successful developments in South Korea. The war has also had wider consequences for the state of international order since 1950. It raised the standing of the United Nations and initiated an era in which political leaders have had to think much harder about taking unilateral action. How did this happen? Let me offer some thoughts from the strategic level.

\section{Building collective interest in world order after 1945}

For most of human history, since tribes and communities coalesced into nation states, security has been determined by one state's capacity to go to war with another. If a more powerful state wanted to take over the territory, people or resources of a less powerful state next door, it was free to try. Smaller states preserved their security by being tough nuts to crack and by allying themselves with larger powers that could threaten retaliatory action against any aggressive third party.

By the end of the First World War, the world generally was so nauseated by the scale of slaughter inflicted by war on military and civilians alike that the League of Nations was formed as a kind of higher level of global governance, to hold belligerence in check. The league's authority was made credible by an international legal structure backed by sanctions, including the use of force. Otherwise force was outlawed as an instrument of national policy. Economic depression, lack of political will and the refusal of the United States to join the league undermined this grand design in the 1930s, and the Second World War resulted. By 1945, it was clear to most national leaders that the world needed more governance, not less, especially in view of the development of the atomic bomb.

The United Nations, formed in 1945, was intended by its founders to do better than the League of Nations. Certainly it had a more impressive membership than the league, for it included the United States and the Soviet Union. Yet any one of the five permanent UN Security Council members could paralyse the world body by use of its veto powers. Both sides in the Cold War sought to circumvent this deficiency by forming 
military alliances on traditional lines. But, for different reasons, neither East nor West could afford to assume that the United Nations had no teeth.

\section{Security in Asia: Collective action by concerned powers}

Curiously, the Soviet Union appeared to do just that when Stalin suspended Soviet participation in the work of the Security Council in January 1950. His aim was to force a change in China's representation, so that Mao Zedong's newly founded People's Republic of China (PRC) would replace Chiang Kai-shek's Republic of China (ROC), now confined to Taiwan. This was a foolish policy for Stalin to adopt when one of the world's major trouble-spots, north-east Asia, was about to erupt.

The Korean Peninsula and the Yellow Sea, sadly for the doughty Korean people, have provided the battlegrounds for great powers, especially China and Japan, to strive for control of north-east Asia for centuries. Once Russia had expanded eastwards to the Pacific seaboard of Siberia, the situation became more complex and more dangerous for those who lived in north-east Asia. In 1898 a group of young nationalist Chinese launched an uprising to protest the humiliations imposed by the demands of foreigners on China. The young Chinese dissidents formed the Society of Harmonious Fists, so foreigners termed them the 'Boxers'. They besieged foreign embassies in Peking, which led eight of the affected powers to form a joint force in order to break the siege, smash the power of the Boxers and restore order. It was a remarkable effort because it was an early example of nations coming together under joint command arrangements, not for the sake of conquest but to restore order, hand power back to a legitimate government, then depart from the scene of conflict. This was largely achieved in the space of two years by a force of 49,000 soldiers, 5,000 marines and 54 warships.

My paternal grandfather was a member of the Australian naval contingent to that conflict, so the Boxer Rebellion of 1900-01 is part of my family history. Because he was a good horseman, Grandfather was chosen to serve with the British Royal Horse Artillery on their ride to Peking, so he had unusually broad experience in his first war-one in which the Japanese, the Germans, the Austrians, the Italians and the Russians were his allies, 
together with the Americans, the British and the French. How radically and how swiftly alignments can change in international politics. But at least the example of a joint action to restore order and then withdraw had been set. Great powers acted as policemen, not conquerors.

Only three years later the Russo-Japanese War broke out-a huge conflagration in which the Japanese emerged so triumphantly that the Americans felt they had to take them seriously as potential enemies and so sought to contain them and develop war plans-Plan Orange in particular-to deal with them if containment did not work.

The Japanese formally incorporated Korea into their empire in 1910 and ruled it harshly for the next 35 years.

The region stayed fairly quiet under Japanese domination during the First World War, but as the Japanese became more assertive in the early 1930s and invaded Manchuria, international will to intervene, especially that of the League of Nations, was sorely tested. It failed. All the league could agree to do was to send a commission, chaired by Lord Lytton, to investigate the scene. The commission's report, a masterpiece of weaselwording, avoided accusing the Japanese of aggression. Despite strongly critical international opinion, the Japanese got away with their use of force and added Manchuria (later renamed Manchukuo) to their domains. They then withdrew from the league, to the widespread dismay of the international community at the time.

\section{The United Nations and Korea, 1945-50}

While the great powers fought for influence during the Second World War, the poor Korean people were the grass under the elephant's feet. Their culture and sense of national identity were suppressed until the defeat of the Japanese in 1945. Then the Koreans might have had a chance to rule themselves. They asked for it, but their hopes were frustrated by great power rivalry and politics once again. The United States and the Soviets divided the Korean Peninsula at the 38th parallel in late 1945, and each side installed nationalist leaders of their own stripe: Kim Il Sung, a communist in the north, and Syngman Rhee, of Western orientation, in the south. The two Korean governments detested each other, and each threatened to take over the other's domain by force. This problem became particularly serious when the Soviet Union and the United States 
withdrew their forces in 1948-49. Syngman Rhee continued to offer belligerent rhetoric to the north, and this was returned with interest by Kim Il Sung-indeed, to the level of a military invasion commencing on 25 June 1950.

The North proved to be much stronger than the South militarily, and the world was presented with the spectacle of a rapid advance, first to take Seoul on 28 June, then to occupy most of South Korea in the following month. US President Harry S. Truman chose to react with firmness lest the Cold War escalate out of control through the West giving the appearance of weakness. The lessons of the 1930s had certainly been learned. After the tensions aroused in 1948-49 by the Soviet attempt to deny British, French and US access to West Berlin by land, and the foundation of the North Atlantic Treaty Organization (NATO) in 1949, President Truman was not prepared to stand idly by while South Korea was absorbed into Kim Il Sung's domain and the increasing Sino-Russo communist monolith. He responded in two ways: by immediately deploying what US forces were available in Japan to help stem the North Korean advance, and by appealing to the UN Security Council to condemn Kim Il Sung's aggression and to authorise retaliatory action under the aegis of the United Nations.

The Soviets were absent from the UN Security Council at this time, and President Truman's desires could not be thwarted by Stalin's veto. So the United States was invited to name a commander-in-chief to drive the invaders out of South Korea on behalf of the United Nations, with forces contributed by a wide range of UN members. Britain immediately placed most of its naval forces in the Far East under General Douglas MacArthur's command, and Australia did likewise. Next day Australia also committed its fighter squadron based in Japan, No. 77 Squadron, Royal Australian Air Force (RAAF). The greatest need, however, was for ground forces, and these were indeed in short supply throughout the manpower-conscious West. The Middle East had looked to be the most likely theatre of war in 1949-50, and Britain required some convincing that it should spare even a single infantry brigade for Korea in 1950. It did so in late July, and Australia offered an infantry battalion, also based in Japan. Altogether, $15 \mathrm{UN}$ members, plus the ROK, placed forces under MacArthur's command. For the first time, a global security organisation had agreed to meet force with force. 


\section{A dilemma for Australia: The Middle East or East Asia?}

Australia, like Britain, had been more focused on the Middle East than on north-east Asia as a likely force deployment area. The Commonwealth was Australia's principal source of friends and allies in 1950, with Britain remaining its principal trading partner and with much of that trade passing through the Suez Canal. It was not a simple matter for the Menzies government to relinquish its obligations to assist Britain in the Middle East and switch its commitments to the United States in Korea. But much was at stake here for Australia. Securing an alliance with the United States was seen by the Minister for External Affairs Percy Spender as a major prize. Menzies doubted Spender's ability to win it, but Spender proved equal to the challenge. He chose his moment well, and in 1951 the terms of the Australia, New Zealand and United States security alliance between Canberra, Wellington and Washington, DC was worked out between the three capitals.

The British Government was not pleased by Australia's formal realignment as an ally of the United States, and quietly tried to discourage the Americans from going this far. But Truman felt obliged to Australia for its support in Korea, and he also recalled the stout performance of the Australian Army when he was in France in 1918 as a captain of artillery. He silenced US Secretary of State Dean Acheson's doubts about the wisdom of yet another alliance by telling him that in a crisis, Australians were good people to have alongside the United States. ${ }^{2}$

This new arrangement did not mean, of course, that Australia ceased to work closely with Britain in security matters. Australia was becoming increasingly involved in the Malayan Emergency, and continued to work with British forces until Harold Wilson's government withdrew its forces from South-East Asia in the late 1960s. But the Korean War did mark a clear divergence of their respective paths.

2 R. O'Neill, Australia in the Korean War 1950-1953, vol. 1: Strategy and Diplomacy, AWM \& AGPS, Canberra, 1981, p. 191. 


\section{The United Nations Command alliance at work: Political control and military reality, 1950}

In the first few months of the war, several NATO governments, including Canada, France, the Netherlands, Belgium, Luxembourg, Greece and Turkey - and other friends of the United States, such as Colombia, Ethiopia, the Philippines, Thailand, South Africa and New Zealandprovided force contingents for Korea. Denmark, Norway, Sweden, Italy and India provided medical units to support the UN Command (UNC). It was indeed an impressive array of national flags to put beneath that of the United Nations, but most of the forces under General MacArthur's command were American and South Korean. It was also quite a handful for the United States to manage, not least because all these allied contingents had their own organisations, operational methods, logistical requirements and political sensitivities. Language was frequently a barrier. A lot of useful lessons were learned all round.

We should now look briefly at the effectiveness of American leadership. The UNC did not have an elaborate structure. Militarily, the land, sea and air forces were commanded by General MacArthur in Japan, with subordinates in South Korea. Politically, control was essentially in the hands of the Truman administration, although it had to run the gauntlet of debate in the United Nations, both in the Security Council and in the General Assembly.

Within that framework, the six Commonwealth nations (the United Kingdom, Canada, Australia, New Zealand, India and South Africa) made a very important subgroup, representing among them many viewpoints, including some that were inclined to be critical of the United States. Debates among the Commonwealth nations tended to mirror those within the UN General Assembly. India's continued approval of key policy decisions was seen as very important, particularly by the United States. If India had gone into open opposition, siding with the Soviet Union and the as yet unrepresented People's Republic of China, the United States would have been in danger of losing its precious UN mandate for intervention in Korea. Thus India's Commonwealth partners had enhanced leverage in both Washington and New Delhi. 
For the 'old dominions' (Australia, Canada, New Zealand and South Africa), the Commonwealth grouping was extremely important throughout the Korean War. Old habits and conveniences proved durable and indeed warm and welcoming in a tough Cold War world. The nexus between these four and Britain was strong. The flow of information between them, and their pattern of consultation, was both extensive and intensive.

In the opening months of the war, when the UNC was struggling desperately to save South Korea from being incorporated into an all-communist Korea, policy differences were few. But once MacArthur's brilliant stroke of landing forces at Inchon had been successfully made, Seoul recaptured and the North Koreans pushed back to the 38th parallel, the nature of the conflict changed. The question now before UNC leaders was not whether South Korea could be saved but whether North Korea should be smashed and conquered.

On this issue many allies were apprehensive. To be fair to the Truman administration, there were major differences between their commander in the field and the government in Washington. MacArthur wanted to invade North Korea up to the Yalu River frontier with China, to remove Kim Il Sung and company from the government and, in effect, hand it all over to Syngman Rhee- the ironic mirror image of what the North had intended to do to the South. The political climate in the United States was not right for Truman to halt MacArthur on the 38th parallel, and indeed there was military logic in attempting to destroy the North Korean armed forces so that they could not repeat their aggression. There was, however, no clear agreement among the UNC allies as to how far this goal should be pursued. Nonetheless, the 27th British Commonwealth Brigade, under MacArthur's command and including the 3rd Battalion, Royal Australian Regiment (3RAR), set off across the parallel and headed towards the Yalu River.

\section{Keeping the war limited, 1950-51}

The most apparent danger in October 1950 was a widening of the war to include China, and the Chinese were explicit about their intentions as MacArthur's forces advanced ever more deeply into North Korea. Britain, Australia, Canada, India, New Zealand and others all had reservations about MacArthur's plans. Diplomatic channels were humming with traffic 
on this theme in October and early November 1950. When President Truman stated, in response to a journalist's question on 30 November, that the use of nuclear weapons against China was under consideration, alarm bells rang loudly in allied capitals. He faced strong criticism from the British and French prime ministers when he met them in Washington on 4 December. The three leaders agreed to establish a consultative system for any decisions on the use of nuclear weapons in the conflict. Truman managed to restore Attlee's confidence that he, Truman, was in charge of US policy, politically and militarily, and that he was not seeking to escalate the war into a nuclear confrontation-which was particularly important because the Soviet Union had demonstrated its own nuclear capability in a test firing in 1949 .

The episode revealed major tensions between Truman and MacArthur, and when, in early 1951, MacArthur attempted to thwart his president by rallying Republicans to the cause of an expanded war, Truman recalled him. The recall came too late to prevent serious damage, because by November 1950 not only were the Chinese powerfully committed militarily in Korea but also, more importantly, MacArthur had divided his forces, leaving them open to defeat in detail. He had sent them forward on offensive missions without the capacity to sustain themselves against the Chinese. The result was a series of Chinese victories on the ground and, by 4 January 1951, Seoul was back in communist hands. The UNC allies were worrying about whether they might not be forced to evacuate Korea altogether.

MacArthur's successor, General Matthew Ridgway, thought in much more appropriate terms than his predecessor. He judged that with the existing balance of forces, the UNC could not only hold its ground without resorting to nuclear weapons but also could begin to grind down the Chinese and North Koreans so effectively that they would want to negotiate an end to their unsuccessful efforts. He let the Chinese Fifth Phase Offensive beat itself out against the UNC's defences across Korea in April and May 1951, as part of which the Battle of Kapyong was fought. He then prepared to drive the communists back and seize the favourable high ground that his forces were to hold while both sides negotiated their way towards an armistice. These talks began on 10 July 1951 at Kaesong and continued at Panmunjom for the following two years. Ridgway's strategy was exactly right for this war. He was fortunate to have available forces that could carry it through without being minced up themselves by the Chinese. 


\section{Sea and air power in a peninsular war}

While we tend to think of the Korean War as having been mainly a contest between the armies of both sides - and that indeed is where the great bulk of the casualties occurred-there were also important naval and air dimensions to the war.

One key strategic factor that seemed to have escaped Kim Il Sung when he launched his attack in mid-1950 was that Korea is a peninsula. The further south a northern aggressor came, the longer were the flanks he had to defend against seaward attack. All his ports were open to bombardment, as were his coastal railway lines, roads and bridges, and any vital facility could be raided by marines coming ashore. The rugged geography of Korea means that most of the communications arteries run along the coast, making sea power all the more influential in a conflict there. Similarly, the further south an invader came, the more he was open to attack by air, both tactical against his ground forces and strategic against his logistics, war industry and sources of food. It took some little time for the United States to marshal, train and equip naval and air forces to perform these missions around and over the Korean Peninsula, but by late 1950 the Korean War had become a land, sea and air conflict in which the UNC had dominance in two of these three elements.

Let us now look at the contributions that the British Commonwealth group of nations made to the effectiveness of UNC operations.

\section{Naval operations}

Because Britain in 1950 still deployed a Far Eastern fleet based in Hong Kong, it was well placed to command the Australian, Canadian and New Zealand naval contingents during the Korean War. This fleet included an aircraft carrier as well as several cruisers, destroyers and frigates, and was able to take responsibility for exerting control over the Yellow Sea and the west coast of the Korean Peninsula. Looking back on three years of deployments of Commonwealth warships in Korean waters, two elements stand out: the navigation, seamanship and hitting power of the smaller ships, especially the frigates; and the strategic role played by the fleet's aircraft. 
For Australia, the Korean War offered the opportunity of deploying its new aircraft carrier, HMAS Sydney. Australia maintained one destroyer and one frigate in Korean waters throughout the war. Sydney replaced the usual British aircraft carrier on the west coast of Korea (one had been stationed in the Far East since 1945) from October 1951 to late January 1952-122 days of continuous service. There is no more complex instrument of war to operate than an aircraft carrier. Australia had acquired Sydney after the Second World War, and was about to acquire a second carrier, HMAS Melbourne, when the Korean War began.

Despite their lack of experience, the ship's company of HMAS Sydney achieved a good record. Her pilots destroyed 66 bridges, seven tunnels, seven railway sidings, 159 railway wagons, two locomotives, 495 junks and other fishing vessels, 15 artillery pieces and more than 2,000 houses. Sydney's aircraft sustained 99 hits by enemy flak, and nine of her aircraft were shot down. Several pilots were killed, and others were rescued by daring action while under enemy fire, on land or in shallow coastal waters. On some patrols, Sydney's pilots and support crew achieved two sorties per day for all aircraft. Given that 38 per cent of Sydney's aircraft returned to the ship in unserviceable condition, this was a notable achievement. (For more on Australia's carrier operations, see Chapter 7.)

As for inshore patrolling and bombardment, it is invidious to pick out a single frigate, but HMAS Murchison's performance was remarkable. The ship, and especially her commanding officer, Commander A.N. Dollard, performed some remarkable feats of navigation-often while under fire between mud banks and along narrow estuarine channels - to attack shore targets or make attempted rescues. Murchison was often a sitting duck for North Korean artillery batteries on shore, only a few hundred yards away, and the vessel frequently took enemy rounds in the hull. When these were armour-piercing shells, they went straight through and out the other side without doing much damage, but a $75 \mathrm{~mm}$ high-explosive shell in the engine room was a different matter. When it happened on 30 September 1951, Murchison was lucky not to have had a high-pressure steam line cut. The ship would have lost the power of one of its two turbines, run aground and been pounded to pieces.

The proficiency of the companies of these two Australian warships demonstrated that in the early 1950s the Royal Australian Navy (RAN) could claim to be taken seriously as a regional force; as such, its effectiveness 
was magnified by its ability to operate within a larger Commonwealth force under British command and as part of a US-led coalition. Australia was one of three countries then operating an aircraft carrier in the Pacific.

\section{Land operations}

It was on land that the Commonwealth, including Australia, made its greatest military contribution in Korea. The war was fought primarily by ground forces, and the other side had clear numerical superiority. The essence of a successful ground strategy for the UNC was threefold: to reclaim the territory of South Korea, to inflict such a level of casualties on enemy forces that they would negotiate a ceasefire, and to avoid precipitating a much larger war by taking action directly against China or the Soviet Union.

This strategy called for well-trained and well-equipped soldiers who could work together in a carefully controlled way and successfully wear down a numerically superior enemy fighting close to his home basesall this without suffering heavy losses themselves. These three objectives called for British force commanders who understood their guidelines and could produce a satisfactory result. Generals Cassells and West, the two Commonwealth Division commanders, and Brigadiers Coad and MacDonald, commanding the 27th and 28th British Commonwealth Brigades, were all equipped by the British Government with a directive that, as well as requiring them to obey the orders of senior (and therefore American) commanders, also required them to make representations directly to the British Government if they thought that their forces were being exposed to undue risk. The American commanders knew about this directive and therefore did not wish it to be put into effect against themselves. If either of the British generals thought there was a possibility of their forces being committed unwisely, all they had to do was go to their US Corps commander and 'wave the paper', as General Cassells termed it. He did not have to do it often, and when he did, it was effective. The two Australian commanders of the 28th Brigade, Brigadiers Daly and Wilton, were also glad to have been under the protection of this directive.

Australia's role in the broad panoply of land forces was modest, being initially limited to one, then two infantry battalions. Nonetheless, they received acclaim for their efforts. The successes of 3RAR, in the defensive Battle of Kapyong then in the attack on Maryang San, are well known, 
and the latter is the subject of detailed analysis in later chapters of this volume. Let me therefore focus on another aspect of the ground campaign that was important right through the three years for which Australian soldiers were committed to the war: patrolling.

Patrolling is a largely unsung art because it is performed by small groups of soldiers, typically 10 to 30 strong. It does not make the headlines, so journalists and the public tend to overlook the powerful contribution that well-conducted patrolling can make. Without a successful patrol program, the enemy will come to dominate no man's land; that makes it easier for him 'to lean on our wire' by conducting offensive operations, thereby keeping the defenders confined, unable to take their own initiatives, and deprived of all the vital intelligence that can be gained from going out and having a close look at the enemy and what he is doing.

When in the early 1970s I interviewed the British commanders of the Commonwealth Division and 27th Brigade, they all emphasised how splendidly the three Australian battalions had performed in the patrolling role. They kept the Chinese well back from their own positions, and they intercepted large parties of Chinese at night as the enemy fought vainly for dominance in no man's land. Australian patrols were aggressive, and at last light the first patrols to go out from the Australian lines could be seen running down through the minefield and barbed-wire gaps to get into no man's land before darkness fell completely. They would go out on a variety of missions: reconnaissance, ambushing, direct combat against enemy patrols where possible and prisoner-snatching from enemy lines. Typically they were led by a platoon commander in his early twenties, or a non-commissioned officer (NCO). They were lonely missions-out there where they could bump into a larger group of Chinese all too easily. They had to depend for their survival on the weapons and ammunition they carried with them. Some patrols could call in artillery fire for protection, but as a patrol commander, you had to know exactly where you were before calling in fire support. Good navigation was essential, and often it was impossible to read a map accurately in the dark. Radio communications were desirable but not always available. Minefields, both enemy and our own, were a problem. And if a member of the patrol was wounded it could be very difficult to get him home again, with four men being required to carry an improvised stretcher. Often the wounded had to struggle along as best they could, even on all fours, because there was no other way to get home. That is how Captain John Salmon made it up 
the icy slopes of Hill 355 on the night of 10/11 December 1952-and he sets off the metal detectors as he goes through airport security nearly 60 years after being hit.

I carried out research on the Korean War in many countries where I could talk to allied veterans. Those who knew anything about the ground war marked out the Australian infantrymen as outstanding patrollers. 'Second to none' is an appropriate characterisation. And given that for nearly two years the ground war was largely static, good patrolling made a vital contribution to the war objective: keeping pressure on the enemy to negotiate without incurring such heavy losses to our own forces that public opinion would cease to support the war effort.

\section{The war in the air}

The air war was extremely important from a UNC perspective because it was a means of offsetting the enemy's superiority in numbers of troops on the ground. Given the context of the war and the need to avoid escalation, the most essential element of UNC air power was the tactical. There was a limited role available for the United States' greatest strength in the air, namely strategic bombing, and all the important strategic targets in North Korea were soon taken out. Australia provided one of only three national air force contingents to operate under the UNC, with the United States and South Africa.

The unit chosen to represent the RAAF was 77 Squadron, which was equipped with Mustangs. They put up a fine performance from the outset and received international acclaim. When the Australian Minister for External Affairs Percy Spender launched his campaign for an alliance with the United States in the Oval Office on 13 September 1950, the one key fact that President Truman knew about Australia's participation in the Korean War to that date was that No. 77 Squadron had done brilliantly. Buoyed by that evidence, Truman was confident in talking down the opposition of his Secretary of State and Joint Chiefs of Staff to taking on yet one more ally. Three weeks before Spender's meeting with Truman, on 22 August 1950, No. 77 Squadron's commanding officer, Wing Commander Lou Spence, had been invested as a member of the Legion of Merit by United States Air Force (USAF) Commander General George Stratemeyer for his outstanding leadership and the squadron's bravery in 
combat. Truman knew that Spence had been awarded this honour, but what he might not have known, when Spender came to the White House, was that Spence had been killed in Korea four days previously.

US and Australian aircrew soon received a sharp reminder that they had entered the jet era. The Soviets, utilising captured German jet fighter swept-wing designs and the British Rolls Royce Nene jet engine, produced under licence from the Attlee government in the USSR, had developed the MiG-15 fighter. This aircraft had excellent high-altitude performance that clearly outclassed that of the propeller-driven Mustangs. The Soviets had passed the MiGs on to the Chinese in mid-1950, and by late that year the danger arose that the Chinese would achieve dominance in the airspace over North Korea sufficient to permit the use of their own ground-attack, reconnaissance and transport aircraft. The Chinese were augmented by highly capable Soviet MiG-15 pilots.

This challenge had to be met and defeated quickly. The United States began to deploy Sabre jet fighters, but it was not so easy for Australia to find a source of supply for jet fighters. The Americans needed every aircraft then rolling off their assembly lines, and the only available option was the British-produced Gloucester Meteor. It was ordered and came into service with No. 77 Squadron on 29 July 1951. It soon became clear that the Meteor could not meet the MiG-15 on anything like equal terms, and it was relegated to the ground-attack role for which it was poorly suited. So the brave and able pilots of No. 77 Squadron put their lives at risk for the last two years of the war with little prospect of achieving much. The squadron lost 37 pilots killed and seven captured. So, despite a good beginning in 1950, No. 77 Squadron had a frustrating period of service for the greater part of the war. The RAAF moved to acquire Sabres as soon as US authorities cleared them for sale, but No. 77 Squadron had to persevere with the Meteors for the remainder of the war.

\section{Diplomacy in the Korean War}

In parallel with the military operations of the war ran intense diplomatic activity. The members of the newly established NATO busily tried to persuade the United States not to leave Europe open to a possible Soviet attack. Countries with interests in the Middle East (particularly Britain and France) sought to come to terms with the problems of resurgent 
Arab nationalism, especially in Egypt, and the challenges of the IsraeliPalestinian relationship. These issues impinged on their relations with the United States.

For Australia, the Korean War represented a call to focus on the security of its own region. Although Britain was still heavily committed to military operations in Malaya, it seemed to most Australians on both sides of politics that they must choose the United States as a principal security partner in the Pacific. While seeking to minimise damage to the British-Australian relationship, the Menzies government now had to forge a partnership with the United States in which Australia would have a significant voice. In essence this meant continuing to impress Washington with Australia's usefulness as an ally and partner. It meant trying to play a stronger part in the Korean War and a major commitment of resources and manpower to a defence build-up in Australia, backed by a near-universal national service training scheme for Australia's young men. Public opinion supported the government and a major reorientation towards the United States was set in motion, which was largely unquestioned until Australia became heavily committed to the Vietnam War.

Australian diplomats also made a direct contribution in Korea. James Plimsoll, the Australian representative on the United Nations Commission on Korea, later the United Nations Commission for the Unification and Rehabilitation of Korea, achieved unusual prominence in Korean affairs. Plimsoll showed the talents that were to take him to the most senior appointments that his department had to offer. He was active in Seoul for much of the period 1950-52 and played a valuable role through developing an effective but not subservient relationship with President Syngman Rhee. The South Korean president was no liberal democrat, and it was all too easy for friction to arise between his government and the Truman administration, not to mention the United Nations itself. Plimsoll showed good judgement in choosing when and how to intervene in these disputes, often succeeding in finding a compromise that kept all parties together on the road to a negotiated truce. Without Plimsoll's mediation it would have been harder to keep the UN coalition together and to limit Rhee's propensity for dictatorial rule. Senior State Department officers praised him warmly when I interviewed them. 


\section{The contributions of the Republic of Korea}

UNC strategy in Korea could not have worked well without a major contribution from the people and leaders of the ROK. Space does not permit more than a brief mention of this factor, but after the first year of the war, during which South Korea was struggling desperately to function as a state, it made a huge contribution to its own deliverance. Two-thirds of the troops in the main defensive lines across the peninsula were South Korean. They took their responsibilities seriously and performed well. The South Korean Government, while far from perfect, also made an important contribution by effectively organising its national resources in support of the UNC. This support ran from the unloading at wharves on the coast to the Korean porterage and support personnel attached to forward allied forces, known, in the case of the Commonwealth Division, as KATCOMs (Koreans Attached Commonwealth Division).

This aspect of the war is notable particularly because it was in marked contrast to allied experience in the Vietnam War, where one of the continually recurring questions was: why aren't our Vietnamese as good as their Vietnamese? In Korea that question had a very short lifetime.

\section{Winding the war down}

Let us return to the theme of this chapter: the setting of a new paradigm in maintaining world order. By the middle of 1951, it was fairly clear to both sides that neither was likely to be able to push the other out of the Korean Peninsula. The balance of forces appeared reasonably stable and robust, and the consequences of escalating the war-into China or Russia for the West, or into Indo-China or Taiwan for the communistsappeared negative, especially in the era of nuclear weapons.

So, in this unusual conflict, both sides agreed in July 1951 to sit down and negotiate a ceasefire that would lead, hopefully, to a peace treaty based on a divided Korean Peninsula. The war continued for a further two years. Many lives, civilian and military, were lost in the process. The soldiers, sailors and airmen at war had to face further hardships and tests of their courage and endurance so that their own side was not seen to be clearly losing on the battlefield, thereby undermining their negotiators or possibly creating an incentive for the other side to escalate. And for 
their valour and commitment in this period, these same soldiers, sailors and airmen deserve praise for persevering when at times the well-known Republican challenge to Truman's policy—-why die for a tie?'—-seemed to have some point to it.

Incentives for concluding an armistice were strengthened by political factors on both sides: the war was becoming increasingly unpopular in the Western states most heavily involved in it, and the Chinese had other priorities on which to focus their limited resources.

By 26 July 1953, everyone had finally had enough, and the armistice was signed. The next day China was given a warning statement-which had been composed by Western powers over several rounds of intense diplomacy during the preceding 21 months - to the effect that if they renewed aggressive activity on the Korean Peninsula, or anywhere else such as Indo-China or Taiwan, the allied response would be swift and powerful. The resulting war would not necessarily be limited, leaving open the interpretation that the United States might use nuclear weapons in responding even to a non-nuclear provocation. President Eisenhower in mid-1953 made sure that the Chinese saw the warning as a serious threat.

This declaration probably had scant effect on Chinese policies in the region, but it offered a smokescreen of menace behind which the West was able to withdraw its forces from the Korean Peninsula. And the Chinese accepted that they needed to devote their efforts more to reconstruction at home than to supporting Kim Il Sung.

\section{Living without a peace settlement since 1953}

The armistice has continued in effect for the past 65 years. North and South Korea, and their respective allies, are still technically at war. And, as we have seen in recent times, the North occasionally commits hostile acts to which the South responds calmly and judiciously. But, despite ostentatious presidential summits, the possibility of a return to serious military operations remains a concern for both sides, and deterrence remains an important justification for continuing high levels of militarisation on both sides of the armistice line. Despite overtures for peace, given the North's development of nuclear weapons, many are still 
concerned that the people on the Korean Peninsula will not be fully at peace with each other for many a long year. But at least those who live in the South are able to continue their development towards a stronger and more prosperous democracy. Sadly, the pitiful condition of those in the North seems likely to persist for many years to come.

There has not been another war of this kind since 1953. The United Nations has sponsored many interventions but not on the scale of the Korean War, and perhaps that is a result of the learning process that occurred on both sides in 1950-51. The United Nations was able to show itself-at least when Stalin was looking the other way-to have teeth and to be capable of using them. That was an improvement over the League of Nations, and a huge improvement over the days preceding the foundation of international organisations dedicated to preserving the peace.

Since 1953, the United Nations has continued to exert itself in the cause of peace and international order, not always successfully, but it has made a powerful difference to outcomes in Africa, the Middle East and SouthEast Asia. The world of the twenty-first century is a very different place from that of the early twentieth century. We owe this change in part to the many men and women of the UN alliance who fought in Korea between 1950 and 1953, and made the point that aggression does not pay. 
This text is taken from In from the Cold: Reflections on Australia's Korean War, edited by John Blaxland, Michael Kelly and Liam Brewin Higgins, published 2020 by ANU Press, The Australian National University, Canberra, Australia. doi.org/10.22459/IFTC.2019.01 